is indebted not only to Mr. Perkins but also to his wife, who accompanied and assisted him. Recent acquisitions in the Geological Department include nearly 300 invertebrate fossils from the Tertiary of the West Indies, collected and presented by Dr. C. T. Trechmann.

The Department of Botany has received the first consignment (2,800 specimens) of Dr. Carl Christensen's fern herbarium. Dr. Christensen is the chief authority on the taxonomy of ferns and is the author of "Index Filicum". It is estimated that the collection comprises more than 14,000 specimens with more than 800 types and 800 cotypes, and in addition fragments of 900 types and co-types; also more than 4,000 drawings, photographs and figures. The herbarium is without doubt the most important collection of ferns in private hands, and will add enormously to the value of the important fern section in the Department. The original drawings (426) illustrating the late E. D. Heatheote's "Flowers of the Engadine" have been presented to the Department by his daughter, Mrs. D. Lee. A further 600 specimens of flowering plants collected by Dr. H. Smith in Western China have been purchased. These are woll collected and preserved and contain several co-types. A collection of 984 lichens from northern Norway and from Baffin Land made by Dr. N. Polunin has been purchased. Although these are rather fragmentary owing to the difficulties of transport, the collections are important because they have been examined by experts and are the token specimens for several distribution records.

\section{Wild-Life of North-West England}

In a lecture to the Blackburn Naturalists' Field Club on November 26, Mr. Eric Hardy mentioned that oyster-catchers, curlew, woodcock, redshank, tawny owls and spotted woodpeckers, are all increasing their nesting range in Lancashire and Cheshire, but the terns are becoming fewer at the well-known Ainsdale sea-bird sanctuary. His subject of "On My Rounds: Notes From a Naturalist's Notebook" described his field studies in Knowsley Park, where great crested grebes, sandpipers, kingfishers and goldcrests are all common nesters and winter wildfowl visiting the great lake are more numerous and varied than at any other Lancashire water; he also showed a series of Dufay natural colour photographs taken at London Zoo this year and some scenes from Whipsnade Zoo, while the small herd of Chartley wild cattle there was compared with photographs of the original herd at Chartley Park, Staffordshire, now extinct, but of which Mr. Hardy has two valuable photographs taken by a Liverpool naturalist in 1891 when the historic herd totalled 52 and tuberculosis had not then broken out. At the Liverpool Cathedral Wild Birds' Sanctuary, said Mr. Hardy, there is a resident population of a few blackbirds, greenfinches, song thrushes and wrens, but in winter chaffinches, great tits, cole tits and golderests visit it and during migration willow-warblers are frequently heard, despite the sanctuary being in an old cemetery in the midst of city slums. From this position inside the city, valuable migration and other observations have been made, as a refuting of the old belief of great migrations of city sparrows to distant harvest fields, but owing to the position of a new masons' shed directly above the sanctuary, it has not been possible to attract many birds this year although the sanctuary is to be reconditioned and improved.

\section{Industrial Research in India}

THE report of the Industrial Research Bureau, Government of India, for the year 1937-38 (Delhi : Manager of Publications), covers the activities of the Industrial Research Council, the Industrial Research Bureau, which has been placed on a permanent basis as from March 1, 1938, and of the Research Branch of the Government Test House in the third year of its working. Special attention has been devoted to the improvement of glass products and, in addition to the work in this field described in a separate chapter of the report, including the improvement of glass furnaces and a survey of glass-making materials, the Council has authorized further work with an improved type of pot furnace. The Research Branch of the Government Test House has been responsible for a considerable amount of work on paints, natural weathering and accelerated weathering tests and also on the construction and performance of dry cells. Work has also been carried out on the use of vegetable oils as fuels and as lubricants for internal combustion engines, and promising results have been obtained with $\beta$-naphthol, diphenylamine, acetylphenylhydrazine and tin naphthenate as antioxidants in blends of castor oil with mineral oils. Information on the manufacture of casein and casein plastics in India is being collected, and a number of investigations on oils and soaps have been allocated. The report includes particulars of publications of the Bureau and of inquiries received.

\section{Research in Education in the United States}

As a step toward canalizing research activities in the field of secondary education, much of which might otherwise run to waste, the United States Office of Education has published a bulletin on "Needed Research in Secondary Education" (Washington, D.C. : Supt. of Documents. Pp. 70. Price $10 \mathrm{c.}$ ). The bulletin is largely based on the monographs of the National Survey of Secondary Education, a collection of important research studies (more than 4,400 pages in all) relating to organization of schools, the pupil, administrative and supervisory problems and personnel, the curriculum and "the extra-curriculum". Before proceeding to indicate specific problems needing investigation, the author discusses some general characteristics of contemporary methods of educational research, distinguishing, for the purpose of evaluating results, three levels of quality : the study of the results of practices (1) in any and all schools as found ; $(2)$ in schools selected for their outstanding merit, and (3) in experimental conditions set up especially for 
the purpose of testing theory. He emphasizes the need for more co-ordinated and co-operative research enterprises such as the college entrance inquiry, undertaken by the Progressive Education Association, into college entrance problems, in which three hundred colleges and thirty schools are participating. Indications of specific problems needing investigation are given under twenty-five headings, corresponding with the several survey monographs already referred to; for example, individual differences, guidance, interpreting the secondary school to the public, and the library.

Co-Operative educational research on an un. precedented scale was undertaken in 1936-37 by sixty universities in the United States under what was known as the Project in Research in Unjversities of the Office of Education. An important feature of the project was the widespread and co-ordinated attack on each of forty selected problems by a number of universities at the same time. The results of the investigations have been reported in a series of bulletins issued by the Office of Education. An interesting example of these is Bulletin No. 17 on "Opportunities for the Preparation of Teachers of Exceptional Children" (Washington, D.C.: Superintendent of Documents. Pp. 58. Price 10 c.). This gives a conspectus of courses concerning the education of eight different groups of exceptional children : blind, deaf, crippled, delicate, speech-defectives, mentally retarded, mentally gifted, and socially or emotionally maladjusted. In recent years such courses have been characterized by an increasing breadth of the pre-requisites for qualifying as a teacher of any one of these groups, candidates being required to have a general knowledge of the teaching methods appropriate for use with normal children and of the needs and problems of exceptional groups other than that chosen for special study. Of the courses concerning the education of exceptionally gifted children, the report notes that "so little is known to-day as to how gifted children should be educated that it is not surprising to find so fow teacher-education institutions presuming to tell their students in any intensive way how to do it".

\section{Suggested New Peace Conference}

THE petition for the holding of a New Peace Conference open to all nations and directed towards remedying the economic and political conditions likely to lead to war, and urging the Government to take, in consultation with the President of the United States of America, the necessary steps to secure the holding of such a Conference, which has been sponsored by the National Peace Council, has received an excellent response. Requests for more than 100,000 petition forms have been received from national organizations, most of which will go to local organizations. The National Peace Council has also issued an appeal for the sum of $\mathfrak{£ 2 , 0 0 0}$ to liquidate an accumulated deficit and provide the expansion of income required for its growing work in mobilizing public opinion in Great Britain in support of efforts to lay the foundations of a general and durable peace.

\section{Activity of the Leonids}

Moнd. A. R. Khan, Begumpet, Deccan, observed the Leonid shower this year on November 14-17, and found that it was more active than it has been for several years. On the night of November 15, in spite of the fact that the radiant was close to the moon, between $21^{\mathrm{h}} 30^{\mathrm{m}}$ and $22^{\mathrm{h}} 30^{\mathrm{m}}$ U.T., out of 31 meteors observed 14 were Leonids. Several of them were bright, the magnitudes in some cases being 0 or even brighter, and most of them were followed by expanding streaks. During the next half hour the numbers fell off, only two out of eleven meteors observed being Leonids. On the following night, between $21^{\mathrm{h}} 5^{\mathrm{m}}$ and $22^{\mathrm{h}} 35^{\mathrm{m}}$ U.T., out of 48 meteors observed, 12 were Leonids, but on November 17, only two Leonids were observed out of a total of eight meteors between $23^{\mathrm{h}} 30^{\mathrm{m}}$ and $24^{\mathrm{h}}$ U.T. The Leonid shower has been rather feeble for some years, but this year it returned with surprising activity.

\section{Another Large Sunspot}

Sunspor frequency remains high, and large spots within the range of naked eye vision have averaged, so far this year, one new group in about every ten days. Very large spots, say of area greater than 1,000 millionths of the sun's hemisphere, have been well represented, no fewer than thirteen having been recorded during the eleven months of 1938. A group of spots, first seen near the sun's east limb on November 23 in solar latitude $14^{\circ}$ north, grew rapidly in the next few days from 150 millionths to 1,950 millionths by November 27. The date of central meridian passage of this large group was November $28 \cdot 8$, and the west limb will be reached on December 5 . On December 6, a region of the sun containing another large spot, which was developing during its approach to the west limb, will come into view again at the east limb.

\section{Announcements}

The Buchan Prize for 1939 of the Royal Meteoro. logical Society has been awarded to Dr. E. W. Hewson, for papers contributed to the Quarterly Journal of the Society during the years 1933-37 dealing with "The Application of Wet-Bulb Potential Temperature to Air Mass Analysis".

The following officers for the session 1938-39 of the University of Durham Philosophical Society have recently been elected: President, Very Rev. C. A. Alington; Hon. General Secretary, Dr. W. A. Clark; Hon. Treasurer, Mr. J. W. Bullerwell ; Editor, Prof. G. W. Todd.

As exhibition of optical aids will be held in Barnsley Grammar School on December 10. During the afternoon, Mr. H. S. Magnay, director of education, Barnsley, will speak on "The Work of the British Film Institute". Further information can be obtained from the Exhibition Secretary at the Grammar School.

Dr. Euakn Korschelt, emeritus professor of zoology and comparative anatomy in the University of Marburg, has been awarded the Goethe medal for art and science. 